\title{
A system dynamics approach to balancing wood supply and demand for sustaining the future industry
}

\author{
$\underline{\text { H. Pumomo }}^{\text {a,b }}{ }^{\text {, L. Abdullah }}{ }^{b}$ and R.H. Irawati ${ }^{a}$ \\ ${ }^{a}$ Center for International Forestry Research (CIFOR), Bogor Barat 16115 \\ ${ }^{a}$ Faculty of Forestry, Bogor Agricultural University \\ Email: h.pumomo@cciar.org
}

\begin{abstract}
The Indonesian furniture industry demonstrates a long chain from production to consumption, from tree growers to producers, and retailers to exporters. The furniture industry provides employment and livelihoods for millions of people. However, an insecure supply of raw materials has produced only poverty and an unsustainable furniture industry. The methods used in this research employed conceptualization, specification, evaluation and use of a model. The model describes the wood supply and demand of the furniture industry, state owned and community teak forests, furniture workshops, and domestic and international markets. It simulates tree dynamics, furniture processing, markets and market impacts on sustainability of the industry. We developed "business as usual", free trade and certification scenarios to understand their impacts on wood and the balance between supply and demand, as well as sustainability of the furniture industry. We recommend scrutinizing plausible impacts prior to the introduction of certification and free trade.
\end{abstract}

Keywords: furniture, forest, supply, demand, sustainability 
Purnomo et al., A system dynamics approach to balancing wood supply and demand...

\section{INTRODUCTION}

Furniture making is the most labour-intensive industry in forestry sector. In 2009, the global furniture trade accounted for USD 135 billion $^{1}$, or approximately $1 \%$ of all world trade in manufactured goods. Furniture is a big business involving a large number of workers. Small and medium enterprises (SMEs) play such an important role in the furniture sector that any decrease in trading volume will increase poverty. Conversely, growth in the furniture industr will increase the number of jobs available, and may reduce unemployment. Increasing value added in the domestic part of the industry's value chain would improve the quality of jobs and provide more decision making and participation for workers and small-scale employers.

In Jepara District, Central Java, Indonesia, the furniture industry contributes about $27 \%$ of the district's economy. Exports were valued at about USD 120 million in 2009. The government, however, has categorized the furniture sector as an industry in decline. Most furniture industry in Indonesia is composed of small and medium enterprises (SMEs). The SMEs have a lower market position than the bigger players. Still, the livelihoods of millions of people along the value chain depend on the sustainability of the furniture industry (Ewasechko, 2005). However, the sustainability of furniture industry is challenged due to a lack of wood supply and fierce competition with new emerging players. These are not only domestic, but also overseas players from China, Vietnam and Malaysia under free trade regimes such as China-ASEAN Free Trade Agreement (CHAFTA). Green furniture, or certification, also provides challenges for furniture players in Jepara to survive and obtain benefits.

Furthermore, the Government of Indonesia is developing regulations that force each district in Indonesia to fulfill its wood needs first before selling to other districts. This is dangerous for Jepara, because its internal wood supply is insufficient. Jepara needs to find a way to balance its wood supply and demand. This paper aims to understand the current situation and its projection. It also looks at how different emerging phenomena, of trade liberalization and certification, affect the sustainability of a culturally rooted industry such as furniture, on which millions of people depend economically and culturally.

\section{CONTEXT AND METHODS}

\subsection{Wood Demand}

Jepara has 11,597 independent furniture enterprises and 384 integrated furniture enterprises. Ninety eight percent of furniture workshops are classified as small-scale businesses, $1.9 \%$ medium-scale and $0.1 \%$ large-scale. The Jepara furniture industry uses mostly teak and mahogany. Most workshops $(89.5 \%)$ produce indoor furniture, while $7.8 \%$ produce outdoor furniture. The remaining workshops produce carvings, handicrafts and calligraphy (Achdiawan and Puntodewo, 2011).

Across 8,289 workshops in Jepara (Table 1), it is estimated that the annual wood consumption is $862,056 \mathrm{~m}^{3}$. This amounts to $82 \%$ of workshops specializing in the domestic market, $9 \%$ in export markets, and the remaining $9 \%$ are active in both. Log yards located in Jepara can provide only $24 \%$ of the total demand. The remaining supply comes from outside Jepara (Achdiawan and Puntodewo, 2011). The annual increase in wood demand is likely to follow the growth of the furniture industry, which is expected to be $7 \%$.

Table 1. Furniture workshops in Jepara (Modified from Achdiawan and Puntodewo, 2011)

\begin{tabular}{|l|r|r|r|}
\hline $\begin{array}{l}\text { Scale of } \\
\text { industry }\end{array}$ & $\begin{array}{c}\text { Mean wood } \\
\text { consumption per } \\
\left.\text { workshop (m } \mathrm{m}^{3} / \text { year }\right)\end{array}$ & Number of workshops & $\begin{array}{c}\text { Total wood } \\
\text { consumption } \\
\left(\mathrm{m}^{3} / \text { year }\right)\end{array}$ \\
\hline Small-scale & 99 & 8,118 & 803,682 \\
\hline
\end{tabular}

\footnotetext{
${ }^{1}$ All currency figures are in US dollars unless otherwise indicated.
} 
Purnomo et al., A system dynamics approach to balancing wood supply and demand...

\begin{tabular}{|r|r|r|r|} 
Medium-scale & 269 & 158 & 42,502 \\
\hline Large-scale & 1,155 & 13 & 15,015 \\
\hline Total & 104 & 8,289 & 862,056 \\
\hline
\end{tabular}

\subsection{Wood Supply}

Perhutani, a state owned company, is the main supplier of raw materials for teak furniture in Java. Its teak forests cover approximately $1,100,534$ ha. However, its teak stand is immature with more than $50 \%$ in age class 1 which is younger than 10 years old (Figure 1).

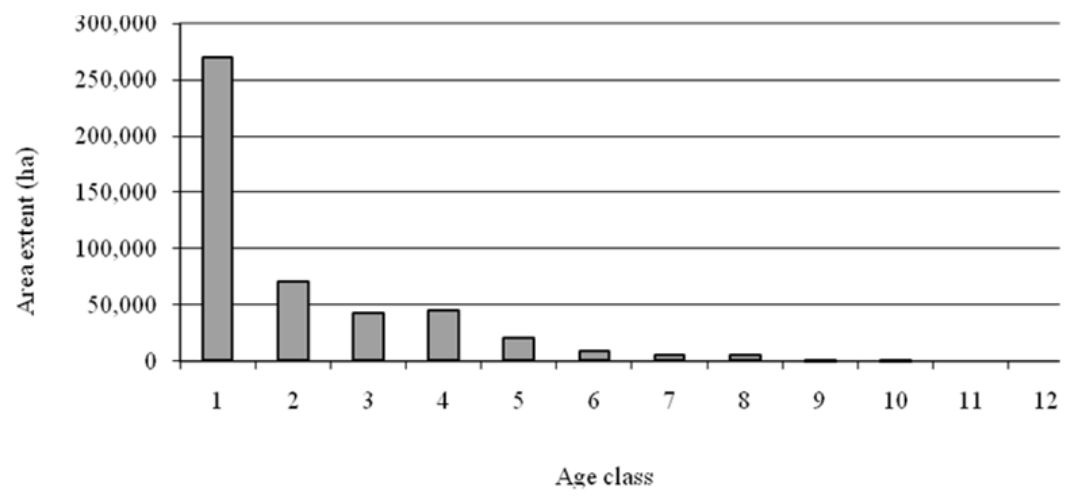

Figure 1. Perhutani teak stand age class structure (Purnomo et al., 2009)

Perhutani's Central, West and East Java Units, can only supply 450,000 m3 annually (Purnomo et al., 2009). Perhutani Central Java, where Jepara is located, can only supply 298,410 $\mathrm{m}^{3}$ per annum (Yovi et al., 2010). Perhutani has an area of 23,627 ha for teak plantation in Jepara, but only 3,175 ha is actually covered by teak $(3,991,552$ individual trees).

Table 2. Teak stand structure of Perhutani in Jepara (Rachmadini, 2011)

\begin{tabular}{|c|c|c|}
\hline $\begin{array}{c}\text { Teak stand } \\
\text { structure }\end{array}$ & Number of trees & Extent (ha) \\
\hline I & $2,535,112$ & 2,282 \\
\hline II & 347,438 & 556 \\
\hline III & - & - \\
\hline IV & - & - \\
\hline V & 16,688 & 27 \\
\hline VI & $1,092,314$ & 1,311 \\
\hline Total & $3,991,552$ & 3,175 \\
\hline
\end{tabular}

Another wood source comes from community teak plantations. In Jepara, the extent of community teak in 2010 was $1,265 \mathrm{ha}$, with 861,555 trees and $22,718 \mathrm{~m}^{3}$ of timber or $18 \mathrm{~m}^{3} / \mathrm{ha}$. Other teak sources may come from the provinces of North Maluku, east Kalimantan, and south east Sulawesi.

The Ministry of Forestry (2004) reported that smallholder teak forests, in all provinces, contained 79.7 million trees. Sofiyuddin (2006) roughly estimated 300 trees per hectare on smallholder teak plantations. Of the 265,708 ha of smallholder teak plantations, 167,066 ha are located in Java and 98,642 outside Java. It has been estimated 
Purnomo et al., A system dynamics approach to balancing wood supply and demand...

that community teak on Java, can supply as much as $400,000 \mathrm{~m}^{3}$ annually. Of the Jepara furniture industry's total teak demand, approximately only $60 \%$ can be covered by Perum Perhutani and community teak. Ten percent of the total demand was fulfilled by other kinds of wood such as mahogany, mindi, and other wood species from the dipterocarpaceae family, and the rest was fulfilled by sengon and other species (Yovi et al., 2010).

\subsection{Methods}

System dynamics (SD) modelling offers a dynamic concept of process-based orientation. It is a method developed particularly for the study of dynamic behavior of complex systems (Forrester, 1961). SD has been used extensively to examine the dynamics of population, ecological, social and economic systems. Influence diagrams are commonly used to conceptually indicate the relationships among system elements. Relationships are sometimes referred to as feedback or casual loops, which can be either positive or negative (Sterman, 2000). The relationships then are converted to stocks and flows, which represent material and information transfers. The SD method comprises: (a) conceptual model development; (b) specification and execution of the model; (c) evaluation of the model; and (d) use of the model (Grant et al., 1997). The developed model was used to understand the trend of the current wood supply and demand, and to develop scenarios to deal with furniture sustainability. The model's realism takes a form of explicit reality, in which the model represents real situations and resources. Costanza et al. (2001) proposed an ecosystem-human interaction characteristics framework for understanding natural resource management. The model was implemented with STELLA, a SD software.

\section{RESULT}

\subsection{Conceptual model}

The model concept is shown in Figure 2. There is a flow of material from forests, logs, furniture, and then rotten or decayed timber. Logs come from Perhutani, community forests and forests outside Jepara. Forests are harvested then processed into furniture. The furniture trade is buyer driven with the buyers setting the price. This price affects the furniture sales of, and then the sales influence furniture delivery, log processing and forest harvesting. CHAFTA can affect the demand of Jepara furniture both domestic and international due to import and international trade. While furniture certification can create premium prices for furniture, at the same time it can increase the wood price.

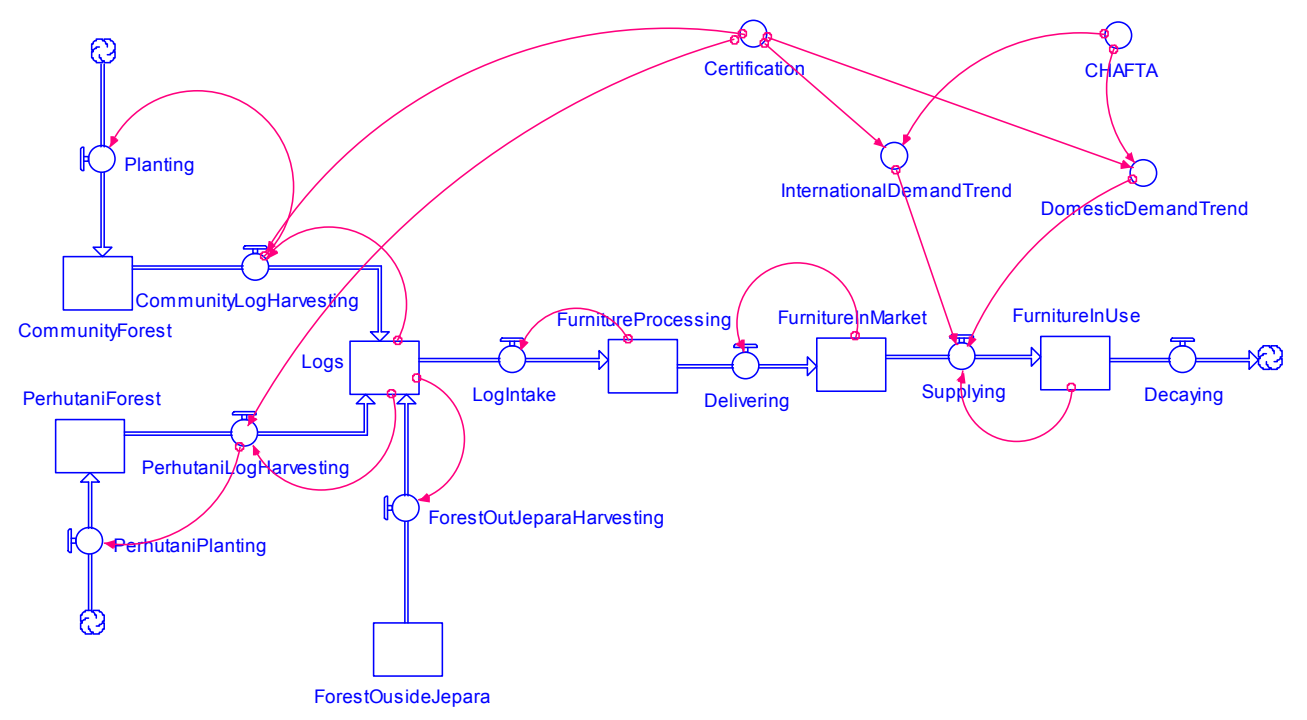

Figure 2. Conceptual model of wood supply and furniture demand 
Purnomo et al., A system dynamics approach to balancing wood supply and demand...

\subsection{Model Specifications : Stand dynamics}

Teak forest plantations were modelled using stand dynamics. The basic concept of stand dynamics estimation is that the forest is represented in a stand table containing trees organised by age classes. Change in the stand table is calculated every year, using periodic measures of plot growth. Outgrowth area (i.e., area extent adding up to higher diameter class area extent), mortality area (i.e., area extent subtracted from the higher diameter class area extent) and recruitment area (i.e., area extent added onto the smallest diameter class area extent) were calculated on the basis of available information. Finally, forest growth can be projected. The projection method involves estimates of recruitment area $(R)$, outgrowth area $(O)$, mortality area $(M)$ as well as logging area $(L)$ and illegal activities $(I A)$. The projected area extent at any age class ' $j$ ' and after a growth period ' $t+1$ ' $\left(A_{j, t+1}\right)$ is defined as

$$
A_{j, t+1}=A_{j, t}+R_{j}+O_{j}-M_{j}-L_{j}-I A_{j}
$$

where $A_{j, t}$ is the initial area extent in age class $j$ at time $t$. Since we used $10 \mathrm{~cm}$ class diameter, each year $10 \%$ of $A_{j, t}$ as $O_{j}$ will add up to $A_{j, t+1}$, while $M_{j}$ and $L_{j}$ are taken from Perhutani data. $M$ comprises loss to fire and natural disasters. $I A$ comprises illegal cutting, land encroachment, illegal tree slashing and illegal grazing.

The trees then harvested with a logging factor of 0.7 . Every $\mathrm{m}^{3}$ tree standing becomes $0.7 \mathrm{~m}^{3} \log$. The logs are then processed into furniture with efficiency rate of $30 \%$. Every $\mathrm{m}^{3}$ of logs become $0.3 \mathrm{~m}^{3}$ of wooden furniture. Due to the limited number of pages other specifications and details of the model components could not be included.

\subsection{Evaluation of the model}

Several researchers (e.g. Vanclay and Skovsgaard, 1997) have advocated the terminology 'model evaluation' instead of 'model validation'. This emphasizes relative utility: a model that is useful for one purpose might be misleading for other purposes. The present model was evaluated using three criteria: the logic of the model and its outputs; and the agreement between projections and expectations. Figure 3 shows the model output under business as usual (BAU). BAU is a condition when the current situation continues. Under the BAU, wood supply tends to remains constant while wood demand increases. The model evaluation reveals that the model was reasonable. This was based on systematic scrutiny of all the relationships within the model, the logic of the model output and the agreement between projections and expectations. This evaluation led to the conclusion that the model complied sufficiently with the basic principles of forestry and economics to provide a basis for discussion of alternative courses of action.

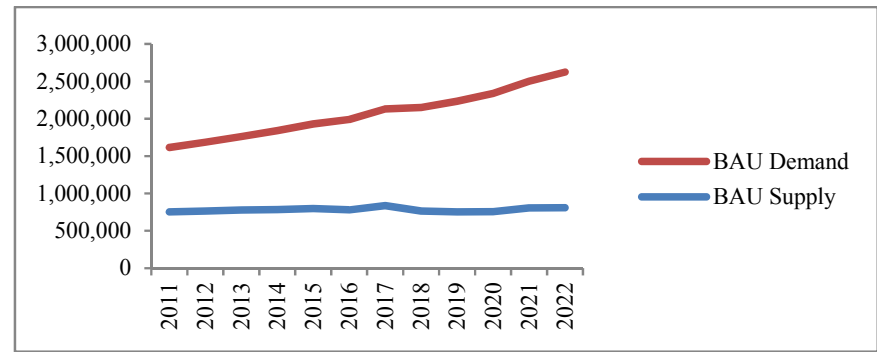

Figure 3. Wood supply and demand in Jepara under BAU scenario (in $\mathrm{m}^{3}$ )

\subsection{Use of the model: Free trade and certification scenarios}

Indonesia and Jepara are facing trade liberalization under the China-ASEAN Free Trade Agreement (CHAFTA). Under CHAFTA we projected that wood demand for Jepara furniture would decrease due to furniture competition with China (Figure 4). This is understandable because competition from Chinese products is perceived to be more of a threat for Indonesian furniture products (including from Jepara) compared with other ASEAN (Association of Southeast Asian Nations) countries. It is hard for Indonesia furniture produces competing with imports from China that sell at lower prices and reasonable quality. The Chinese furniture, particularly for light weight timber and with no carving, is cheaper than Jepara furniture. It could feasibly steal 
Purnomo et al., A system dynamics approach to balancing wood supply and demand...

Jepara's market share of international trade in furniture. Some people do not really care what type of furniture they have, they just need furniture. In this case, the price will be the deciding factor when choosing furniture. . It, however, does not significantly affect to wood supply. Jepara fulfills its demand by buying logs from outside Jepara. So, Jepara will still grow teak although Jepara furniture is challenged by CHAFTA.

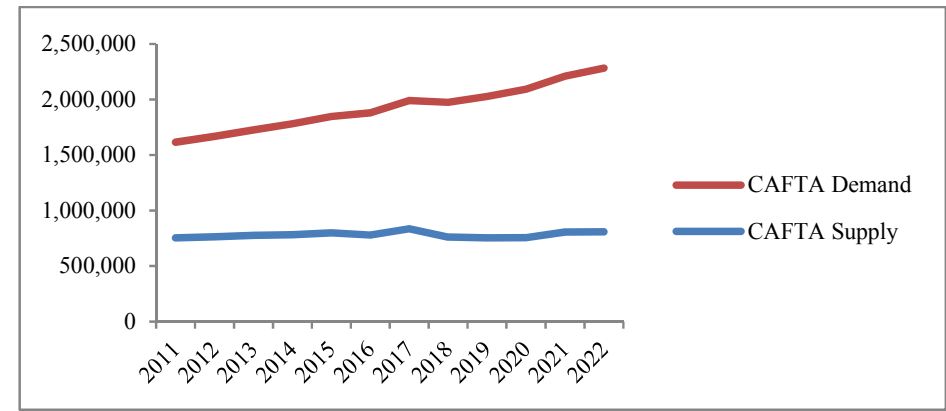

Figure 4. Wood supply and demand under CHAFTA scenario (in $\mathrm{m} 3$ )

Certification can also decrease the demand for wood due to a decrease in demand for furniture. If certification is applied globally then demand for Jepara furniture could decrease, because Jepara would not be able to fulfill the certification requirements. The majority of Jepara furniture is uncertified. Although, certified furniture promises premium prices, the cost of certification is quite high and there is no guarantee that premium prices will be realized. Equally, certification cannot automatically encourage people to grow teak. Entering the certification process in not without cost, and is mostly too high and too complicated for the local community. That is why certification does not significantly affect wood supplies.

\section{DISCUSSION}

The current Jepara wood demand is fulfilled by wood from outside Jepara. This situation is projected to continue happening in the future. Although the wood demand increases, incentive to grow more teak for furniture does not occur in Jepara. This is because the profit margin for growing teak is very low. The forest growers do not receive much in the way of added value from the furniture industry (Purnomo et al. 2009). This situation, in the long term, is very dangerous particularly when the Government of Indonesia requires each district to be selfsufficient in wood.

Both scenarios of CHAFTA and certification can decrease wood demand, but will not affect wood supply. Indonesia was willing to be part of CHAFTA with hope that the furniture export to China would increase. However, it did not happen. To the contrary, imported furniture from China has increased and the demand for Jepara furniture has decreased. Consequently, the decrease in demand will decrease the wood demand. However, the wood supply is insensitive to this decrease, because the market share of wood in Jepara is still low.

Certification was intended to, among others, sustain forests and improve the well being of local communities. If it is applied to small-scale enterprises that use uncertified wood then certification can be a barrier rather than an endorsement to grow tress. This is due to the complicated processes of the certification itself. Certification is not the answer to increase furniture prices. That is why certification is not effective in creating incentives to grow trees.

To balance wood demand and supply in Jepara clearly CHAFTA is not the answer. However, CHAFTA can work if Jepara were to specialize in handmade carved furniture. This type of product could compete with China as well as other ASEAN countries. Jepara needs to focus on its uniqueness and particular furniture market segments. If these products are appreciated by the CHAFTA market then demand will increase and incentive to grow trees for carving and handmade items will increase. And since carving and handmade items are high end products then the increase in teak growing may narrow the gap between wood supply and demand in Jepara. 
Purnomo et al., A system dynamics approach to balancing wood supply and demand...

Increasing furniture prices is the right way to increase wood prices and in turn to increase incentive to grow trees. If wood prices increase, but it is not followed by increasing furniture prices then the furniture industry will collapse. Furniture prices are important for the sustainability of the furniture industry and to balance wood supply and demand.

\section{CONCLUSION}

The furniture industry demonstrates a long chain of production to consumption, from tree growers, processing to market. The sustainability of the furniture industry in Jepara is challenged because of an imbalance in wood supply and demand. With the aim of government of Indonesia to make every district self-sufficient in wood, Jepara clearly needs to find a way to fulfill its wood needs. From the simulation, it is very clear that CHAFTA and certification are not straightforward answers for the problems Jepara is facing. Instead of incentivizing the local community to increase wood supply, CHAFTA and certification can jeopardize it. Increasing furniture prices is a must to encourage the growing of teak. If CHAFTA and certification can increase the furniture prices then Jepara will receive direct benefits from both.

\section{REFERENCES}

Achdiawan R, and Puntodewo A. 2011. Livelihood of Furniture Producers in Jepara. Furniture value chain project annual report 2011. CIFOR. Bogor

Costanza R, Low BS, Ostrom E, Wilson J. (Eds.), 2001. Institutions, Ecosystems, and Sustainability. Ecological Economic Series. Lewis Publishers, Boca. 270p.

Forrester JW, 1961. Industrial Dynamics. MIT Press, Cambridge, MA.

Grant JW, Pedersen EK, Marin SL. 1997. Ecology and Natural Resource Management: System Analysis and Simulation. Addison-Wesley, Reading, UK.

Ministry of Forestry [MOF]. 2004. Ministry of Forestry of Republic Indonesia. Potency of Community Forest: MOF and Central Agency of Statistics report. Ministry of Forestry, Jakarta.

Purnomo H, Guizol P, Muhtaman DR. 2009. Governing the teak furniture business: A global value chain system dynamic modeling approach. Environmental modelling and software, 24 (12): 1391-1401.

Rachmadini MC. 2011. Stand dynamic potency and forest management system in Jepara. Unpublished student research report. Bogor agricultural university.

Sofiyuddin M. 2006. Survey of Standing Stock of Teak Community Forest in Wonogiri Central Java. Unpublished student research report., Bogor Agricultural University.

Sterman JD. 2000. Business Dynamics: Systems Thinking and Modeling for a Complex World. McGraw-Hill Higher Education, Boston.

Yovi EY, Bahruni, Nurrochmat DR. 2010. Wood Sources for Jepara Teak and Mahogany Furniture. Furniture value chain project annual report 2011. CIFOR and Bogor Agricultural University. Bogor

Vanclay JK, Skovsgaard JP. 1997. Evaluating forest growth models. Ecological Modelling 98 (1), 1-12. 